\title{
Debriefing the President: The Interrogation of Saddam Hussein. By John Nixon. New York: Penguin Random House, Blue Rider
} Press, 2016.

Mark Roberts

Subject Matter Expert

Follow this and additional works at: https://digitalcommons.usf.edu/jss

pp. $125-127$

\section{Recommended Citation}

Roberts, Mark. "Debriefing the President: The Interrogation of Saddam Hussein. By John Nixon. New York: Penguin Random House, Blue Rider Press, 2016.." Journal of Strategic Security 10, no. 2 (2017) : 125-127. DOI: http://doi.org/10.5038/1944-0472.10.2.1602 Available at: https://digitalcommons.usf.edu/jss/vol10/iss2/10

This Book Review is brought to you for free and open access by the Open Access Journals at Digital Commons @ University of South Florida. It has been accepted for inclusion in Journal of Strategic Security by an authorized editor of Digital Commons @ University of South Florida. For more information, please contact digitalcommons@usf.edu. 


\section{Debriefing the President: The Interrogation of Saddam Hussein. By John Nixon. New York: Penguin Random House, Blue Rider Press, 2016.}




\section{Debriefing the President: The Interrogation of Saddam Hussein. By John Nixon. New York: Penguin Random House, Blue Rider Press, 2016. ISBN: 978-o-399-57581-5. Pp. iv, 242, $\$ 25.00$.}

John Nixon was an analyst at the Central Intelligence Agency (CIA) for thirteen years. He earned B.A. and an M.A. in History and an M.A. in National Security Studies. When he joined the CIA, he studied and analyzed Iran and Iraq and delved deeply into CIA files about then Iraqi leader Saddam Hussein to become a subject matter expert. When U.S. forces captured Saddam Hussein, Nixon was his debriefer, spending weeks at close quarters with the former dictator. Nixon is a gifted writer and he employs his academic and analytic skills well in telling his story. The book is captivatingly easy to read and flows like a novel.

Nixon describes his early experiences at the CIA, where he worked for a number of risk-averse bureaucrats who did not think strategically. He derides the rampant cronyism as a factor that stifles intellectually honest debate about what the intelligence gathered really means. He speaks of his frustration that the CIA's lack of resources on the ground in Iraq before the war hampered its ability to perform meaningful analysis.

Based on his experiences with Saddam Hussein, Nixon posits that the United States underestimated what it was getting into in Iraq, and certainly did not understand the Iraqi dictator, misreading him on multiple levels. He relates that Saddam viewed Sunni extremism as a threat and thought that the U.S. would ally with him to combat it. Saddam feared Wahhabism and Iranian adventurism and thought his interests and those of Washington were compatible.

Nixon states that had the U.S. left Saddam Hussein in power, the so-called Islamic State in Iraq and Syria (ISIS) would have never come into being. Saddam's removal created a power vacuum that created the conditions leading to a vicious sectarian bloodbath. Nixon repeatedly outlines how the U.S. did not understand before the invasion of Iraq the potential consequences of removing Saddam Hussein from power. This was due in part to a lack of insight on how Saddam viewed the world from inside his insular bubble, and the actual political and sectarian elements in Iraqi society. Nixon observes that Saddam studied and was fascinated by history, but lacked the intellect to learn its lessons. Saddam was instead focused on internal security (maintaining his grip on power) and his leisure pursuits (Saddam fancied 
himself a writer and had penned a novel). According to Nixon, Saddam was more concerned with writing fiction than governing (or ruling) Iraq.

As he got to know Saddam, Nixon came to understand that Saddam's protective detail, some 4,500 operatives strong, was layered, redundant, and all in the family. Saddam believed that family was the best insurance against betrayal. Nixon was aghast to find that when the U.S. invaded Iraq, Saddam had no escape plan. Viewed in this light, Saddam's lack of an escape plan explains why the U.S. did not know where to look for him. He sought refuge with trusted relatives and friends, moving about frequently. Nixon states that Saddam was loyal to those who showed him loyalty.

From his sessions with Saddam, the author notes that Saddam was highly suspicious of everyone, charismatic, tough, shrewd, and manipulative in an attempt to control whatever situation in which he found himself (including his debriefing sessions). Nixon recounts that he was surprised and somewhat dismayed that the U.S. Government had never prepared to capture Saddam alive. He outlines how the guidance on debriefing Saddam changed often as the attorneys zig-zagged their way across the legal landscape with conflicting directives. He expresses his frustration that there was no plan to debrief Saddam - he was told to just do it.

Nixon shares that Saddam understood Iraq holistically but had no grasp on international relations. A narcissist, Saddam viewed himself as a great leader and everyone else as his inferior. When asked a question he did not want to answer, Saddam feigned ignorance, asking Nixon to refresh his memory to see what Nixon knew. Saddam's style of leadership was ad lib; he did not discuss, analyze, seek consensus from, or collaborate with, his senior leaders.

As their sessions went on, Saddam acknowledged to Nixon that he could have done more to create a clear picture of Iraq's Weapons of Mass Destruction (WMD) program to the U.S. When the U.S. invaded Iraq in 2003, Saddam was surprised. He had no plan to combat the U.S. and did not understand military doctrine.

In the final chapters of the book, Nixon gives his unvarnished view of the CIA, how analysis is employed, and former President George W. Bush. Nixon posits the CIA should tell the President what he needs to know rather than let the White House tell the CIA what interests it - the "service" approach. 
"As the conflict with Iraq loomed, the service approach became even more entrenched. It can work wonders if the policymaker is steeped in the issues, knows which questions to ask, and is brave enough to make decisions regardless of their political impact. But the service approach can have disastrous results when the president has strong preconceptions, a short attention span, and little time until the next election. I always felt that deciding what was important should be the job of the analysts, because policymakers are often too busy to know what they should be focusing on....In effect, we provided intel fixes without telling policymakers where an issue was headed or what outcomes to expect" (188-9).

Nixon exhibits great disappointment in his assessment that President Bush did not understand Saddam and misread who he was and what he did what he did. He then writes that President Bush and Saddam were similar in multiple ways:

"Both had haughty, imperious demeanors. Both were fairly ignorant of the outside world and had rarely traveled abroad. Both tended to see things as black and white, good and bad, or for and against, and became uncomfortable when presented with multiple alternatives. Both surrounded themselves with compliant advisors and had little tolerance for dissent. Both prized unanimity, at least when it coalesced behind their own views. Both distrusted expert opinion" (207).

Nixon's recounting of Saddam and his observations rightly belong in any leadership study of dictators and international strong men. His view of President Bush does not hold back any punches and borders on the derisive. He rails against how business is done in Washington and calls for a change in the way analysis is done and used. It seems ironic that a historian who laments how policymakers have failed to learn from history does not himself see how he has not learned how business is done in Washington.

Mark Roberts, Subject Matter Expert 